\title{
Efektivitas Psikoedukasi Wawasan Kebangsaan untuk Menurunkan Kecenderungan Radikalisme pada Mahasiswa
}

\author{
Eko April Ariyanto', Sayidah Aulia ul Haque1, Achmad Rizal Syafii ${ }^{1}$ \\ 1Fakultas Psikologi, Universitas 17 Agustus 1945 Surabaya \\ eko_ariyanto@untag-sby.ac.id
}

Article History:

Received

15 Oktober 2019

Reviewed

27 November 2019

Revised

4 Desember 2019

Accepted

11 Desember 2019

Published

30 Desember 2019

\begin{abstract}
This research is motivated by the growing understanding of radicalism in Indonesia, including among the young generation of Indonesia. The younger generation should be the hope of the nation to continue the struggle of the predecessors to advance Indonesia, but if the young generation has been exposed to radicalism, it is necessary to provide an intervention in this case in the form of psychoeducation. The purpose of this study was to determine the effect of "Nationality Insight" psychoeducation on the emergence of radicalism in students. This study uses a comparative quantitative approach with data collection using non-probability sampling techniques in the population at the University August 17,1945. The results of the Paired Sample T Test obtained significance of $0.104>0.05$. The results of the Paired Sample T Test on the pre-test and post-test scales in the group treated in the form of Nationality Psychoeducation obtained a significance of $0,000<0.05$. The results of this study prove that the "National Insight" psychoeducation method is effective in reducing the attitude of radicalism to students.
\end{abstract}

Keywords: National Insight, Radicalism, Students

\begin{abstract}
Abstrak. Penelitian ini dilatarbelakangi oleh paham radikalisme yang makin berkembang di Indonesia, temasuk pula di kalangan generasi muda Indonesia. Generasi muda seharusnya menjadi harapan bangsa untuk melanjutkan perjuangan pendahulu memajukan Indonesia, namun bila generasi muda telah banyak terpapar paham radikalisme maka perlu diberikan sebuah intervensi yang dalam hal ini berupa psikoedukasi. Tujuan dari penelitian ini adalah untuk mengetahui pengaruh psikoedukasi "Wawasan Kebangsaan" terhadap munculnya paham radikalisme pada mahasiswa. Penelitian ini menggunakan pendekatan kuantitatif komparatif dengan pengambilan data menggunakan teknik non probability sampling pada populasi yang ada di Universitas 17 Agustus 1945. Hasil uji Paired Sample T Test diperoleh signifikasi sebesar $0.104>$ 0.05. Hasil uji Paired Sample T Test skala pre-test dan post-test pada kelompok yang diberi perlakuan berupa Psikoedukasi Wawasan Kebangsaan didapatkan signifikansi sebesar $0.000<0.05$. Hasil penelitian ini mebuktikan bahwa metode psikoedukasi "Wawasan Kebangsaan" efektif dalam menurunkan sikap radikalisme pada mahasiswa.
\end{abstract}

Kata kunci: Wawasan Kebangsaan, Radikalisme, Mahasiswa

\section{Pendahuluan}

Kehidupan berbangsa dan bernegara yang dilandasi unsur kerukunan, toleransi, saling menghormati dan gotong royong merupakan prinsip yang harus terus dikuatkan. Prinsipprinsip tersebut dibangun dari kesadaran bersama seluruh warga negara bahwa keberagaman telah menjadi unsur pembeda sekaligus unsur pemersatu. Seperti diketahui, Indonesia 
merupakan negara kesatuan yang terdiri atas 17.504 pulau, dengan luas wilayah 7,81 juta km2, terdiri dari lebih dari 1340 suku bangsa serta 1.211 bahasa (BPS tahun 2010). Persoalan yang muncul akibat adanya perbedaan seharusnya tidak menjadi unsur yang memecah belah kesatuan maupun persatuan bangsa.

Keberagaman lainnya yang terdapat di wilayah Indonesia ialah unsur agama dan aliran kepercayaan yang tumbuh dan berkembang dengan rukun. Kepercayaan terhadap agama ini secara konstitusi telah mendapat perlindungan hukum, sehingga seluruh warga masyarakat memiliki hak yang sama untuk memeluk agama dan beribadah sesuai dengan unsur kepercayaannya tersebut. Secara konstitusional perlindungan terhadap pemeluk agama tertuang dalam pasal 28E ayat (1), (2), pasal 28I ayat (1) kemudian pasal 29 ayat (2) UndangUndang Dasar Tahun 1945 (UUD 1945). Keberadaan agama sebagai unsur pemersatu telah termuat dalam sila pertama Pancasila yaitu Ketuhanan Yang Maha Esa. implementasi sila pertama ini akan menjiwai sila-sila Pancasila yang lain, artinya bahwa seluruh kehidupan berbangsa dan bernegara berlandaskan nilai-nilai dan norma-norma agama. Melalui unsur tersebut, setiap manusia dapat saling berinteraksi, toleransi, rukun, dan saling menghormati. Perbedaan dalam memeluk agama bukanlah suatu hambatan menciptakan kerukunan antar umat beragama.

Sebagai umat yang mayoritas, pemeluk agama Islam di negeri ini menjadi kunci bagi terciptanya kerukunan antar umat beragama. Nilai-nilai keislaman dan keyakinan bahwa islam adalah Rahmatan lil Alamin turut membentuk kepribadian umat islam sebagai individu yang menjunjung tinggi keberagaman dan kemaslahatan bagi seluruh umat beragama lainnya. Praktek toleransi beragama ini, secara langsung telah diajarkan di setiap pondok pesantren di Indonesia. praktek pluralisme dan toleransi beragama yang dijadikan landasan kebijakan bagi program pondok pesantren adalah pemikiran dan sikap inklusif dalam beragama. Pemikiran yang percaya bahwa agama lain tetap mampu menjadi juru selamat bagi umat, namun kriteria tertinggi dari keyakinan dan kepercayaan tersebut tetap berada pada agamanya sendiri. Pengajaran di pondok pesantren diutamakan pada kebenaran ajaran islam sebagai agama yang memberikan rahmat bagi seluruh dunia, namun hal tersebut tidak menjadi faktor untuk mengurangi ataupun merendahkan agama yang lain.

Posisi agama Islam sebagai unsur pemersatu di Indonesia, berada pada titik terendah pasca kejadian bom bali 1 pada 12 oktober 2002. Ledakan yang terjadi di Paddy's Pub dan Sari Club di Jalan Legian, Kuta Bali tersebut mengakibatkan 204 korban jiwa. Kejadian serupa terjadi kembali pada 1 Oktober 2005, satu bom meledak di Kuta dan dua lainnya di Jimbaran Bali. Kejadian tersebut menyebabkan 23 orang meninggal dan 196 Lainnya menderita luka-luka (https://id.wikipedia.org/wiki/Bom_Bali_2005). Para pelaku ledakan bom di tahun 2002 dan 2005 tersebut teridentifikasi sebagai umat muslim dan organisasi islam terlarang Jamaah 
Islamiya (JI) yang saat itu berafiliasi ke Al Qaeda di Timur Tengah. (Global Terrorism Database/GTD) https://www.start.umd.edu. Sejak tahun 1970 hingga tahun 20018 telah terjadi 761 aksi terror bermotif agama maupun politik. Prasangka agama pasca serangan Bom tersebut semakin membesar sehingga memunculkan kecurigaan-kecurigaan antar sesama umat muslim ataupun antar agama. Kelompok-kelompok muslim tertentu tersudutkan karena diangggap sebagai pelaku ataupun sebagai inisiator ledakan bom di Bali tersebut.

Pada setiap aksi teror menimbulkan kerusakan infrastuktur dan korban jiwa. Dari 761 teror yang pernah terjadi, tidak semua aksi terror menyebabkan adanya korban jiwa. Sebanyak 323 (tiga ratus dua puluh tiga) aksi teror yang telah dilakukan tidak menimbulkan korban meninggal dunia meskipun kerusakan secara fisik dan korban luka tetap terjadi. Sebanyak 86 (delapan puluh enam) aksi terror menimbulkan korban jiwa antara 1 sd 10, 39 (tiga puluh Sembilan) aksi terror menyebabkan 11 sd 50 orang meninggal dunia, tiga (3) aksi teror menyebabkan 51 sd 100 orang meninggal dunia dan lima (5) aksi teror lainnya menyebabkan rata-rata 101 orang meninggal dunia. Teror yang menyebabkan jumlah korban paling besar terjadi antara tahun 1995 - 2004 dan tahun 2013 - 2016.

Aksi teror tersebut merupakan bentuk nyata adanya paham radikalisme yang berkembang. Stankov (2018) menyatakan radikalisme sebagai Militant Extrimist Mindset (MEM) yaitu seperangkat keyakinan, perasaan, pemikiran dan motivasi diantara mereka yang merencanakan atau aktif terlibat dalam terorisme. MEM merupakan ungkapan yang mewakili dua istilah terkait dengan radikalisme dan ekstrimisme yang memiliki konotasi psikologis. Dengan adanya pola pikir radikal mempermudah perilaku seseorang mengarah pada aksi terorisme. Encyclopedia Britannica mendefinisikan terorisme sebagai penggunaan sistematis kekerasan untuk menciptakan iklim ketakutan yang umum dalam suatu populasi yang menghasilkan tujuan politik tertentu.

Radikalisme, dalam Kamus Besar Bahasa Indonesia (Depdiknas, 2002), adalah 1) paham atau aliran yang radikal dalam politik; 2) paham atau aliran yang menginginkan perubahan atau pembaharuan sosial dan politik dengan cara kekerasan atau drastis; 3) sikap ekstrem dalam aliran politik. Radikalisme bersifat kontekstual, memiliki berbagai perwujudan; mulai dari perjuangan politik hingga menyampaikan gagasan ataupun pikiran di media (Cahill, 2012). Apa yang dianggap sebagai radikal di suatu waktu/tempat, tidak selalu dianggap radikal di waktu/tempat lain.

Radikalisme juga berarti kesiapan individu untuk terlibat dalam aksi politis ilegal dan disertai kekerasan (Moskalenko dan McCauley, 2009). Selanjutnya Moskalenko dan McCauley (2009) menjelaskan radikalisme memiliki penilaian berbeda terhadap situasi politik yaitu membenarkan bahkan membutuhkan tindak kekerasan menyangkut politik (political violence) sebagai satu-satunya jalan untuk mengubah kondisi politik. 
Radikalisme merupakan sebuah paham yang disebabkan oleh ketidakpuasan individu terhadap nilai-nilai dan praktik-praktik tertentu sehingga menyebabkan ketidakpastian di dalam diri Individu. Kondisi demikian pada akhirnya mengarahkan Individu untuk bergabung di dalam kelompok-kelompok radikal (Hogg, Meehan, \& Farquharson, 2010).

Mas'ud Halimil dari BNPT (Badan Nasional Penanggulangan Terorisme) dalam acara $\begin{array}{llll}\text { RPR } & \text { (Rakor } & \text { Penanggulangan }\end{array}$ (http://diktis.kemenag.go.id/NEW/index.php?berita=detil\&jenis=news\&jd=162.\#.XeyoM2)5 uLtQ) menyampaikan bahwa pemahaman keagamaan masyarakat berada pada tingkat "waspada" (66,3\%). Kemudian juga pada tingkatan kedua yang tidak kalah mengkhawatirkan adalah kalangan mahasiswa yang menjadi sasaran ideologi radikal berada pada tingkat "hati-hati" $(20,3 \%)$. Pada tingkatan ketiga yang memiliki tingkat "bahaya" adalah kalangan pengurus masjid dan guru sekolah madrasah sebesar $(15,4 \%)$. Masih menurut Mas'ud, salah satu target penyebaran dan perekrutan aksi radikalisme adalah kelompok muda yang dianggap sebagai usia 'pengantin' yaitu antara 18 - 31 tahun.

Usia muda dimana termasuk di dalamnya adalah kalangan mahasiswa merupakan kelompok sasaran ideologi radikalisme, hal ini juga nampak dari tertangkapnya lima dari tujuh belas jaringan Pepi Fernando yang pada saat itu masih berstatus sebagai seorang lulusan starta satu (S1) (Saifuddin, 2011).

Radikalisme sendiri dapat diprediksikan dari beberapa faktor diantaranya adalah faktor psikopatologis, kognitif dan psikososial (Abdrabo Solimah, Tarek Bellaj, Maher Khelifa, 2016). Faktor psikopatologis mendukung gagasan bahwa gangguan kepribadian memainkan peran kunci dalam memprediksi radikalisme. Perilaku radikal mirip dengan kenakalan, seseorang yang radikal menderita insting kelekatan yang buruk sehingga mereka tidak dapat merasakan simpati atau empati (Locicero \& Sinclair, 2008 dalam Abdrabo Solimah, Tarek Bellaj, Maher Khelifa, 2016). Faktor kognitif yang menyebabkan munculnya perilaku radikal ialah pengambilan keputusan rasional dengan gaya keputusan kompleksitas kognitif ketidakpastian dan gaya kognitif. Apabila dicermati dari faktor kognitif tersebut, sebenarnya individu radikal sadar akan keputusan dan hasil dari perilaku yang dilakukannya.

Selain itu faktor lain yang bisa menjadi prediktor radikalisme adalah faktor psikososial. Pencarian keadilan dan intoleransi memiliki efek pada radikalisme. Individu yang radikal cenderung merasionalisasi untuk bergabung dengan kelompok teroris dengan mengutip ketidakadilan pemerintah yang merampas kebebasan, martabat, keamanan dan identitas mereka (Taylor \& Quayle, 1994).

Kecenderungan pola pikir yang salah, pengambilan keputusan yang tidak tepat serta adanya intoleransi in ila h yang dapat mempengaruhi munculnya perilaku radikal (Turner, 1984). Oleh karenaitu dibutuhkan upaya-upaya penanggulangan agar ideologi radikalisme tidak 
makin tersebar, pemerintah Indonesia sendiri telah mengeluarkan Perpres nomer 46 tahun 2010 dan Perpres nomer 12 tahun 2012 yang menugaskan BNPT sebagai koordinator pelaksanaan penanggulangn

terorisme (diktis.kemenag.go.id/NEW/index.php?berita=detil\&jenis=news\&jd=162.\#.XeyoM25uLtQ).

Selain itu langkah yang dapat diambil adalah melakukan psikoedukasi untuk memberikan pembahaman yang kuat bagi mahasiswa supaya tidak terlibat dalam paham radikal. Psikoedukasi adalah layanan psikologi yang umumnya bersifat pencegahan bagi individu dalam sebuah kelompok besar, dapat berupa training (pelatihan) maupun non training (non pelatihan seperti brosur, film edukasi dan lain-lain) dan memiliki tujuan untuk menambah wawasan, keterampilan, serta perubahan sikap pada individu.

Menurut Sutrisno (2012) pelatihan merupakan proses pendidikan jangka pendek yang menggunakan prosedur sistematis dan terorganisir dengan mempelajari pengetahuan dan keterampilan teknis untuk tujuan-tujuan tertentu. Sedangkan As'ad (2001) dalam Sutrisno (2009) mengemukakan bahwa pelatihan menyangkut usaha-usaha berencana yang diselenggarakan agar tercapai penguasaan akan keterampilan, pengetahuan, dan sikap-sikap yang relevan terhadap pekerjaan. Kirkpatrick (1959) dalam Lawson (2006) mengemukakan 4 model evaluasi dalam pelatihan yaitu, evaluasi reaksi, evaluasi belajar, evaluasi perilaku, dan evaluasi hasil. Meskipun pelatihan memiliki 4 macam evaluasi, namun pemberian evaluasi pada peserta pelatihan tidak harus memenuhi 4 hal tersebut karena dapat disesuaikan kembali dengan tujuan pelatihan.

Melalui psikoedukasi para mahasiswa diharapkan memiliki ketahanan individu untuk menghadapi berbagai informasi yang menyesatkan pemahaman mereka. Ketahanan tersebut didapatkan dari adanya informasi yang utuh mengenai sebuah konsep mengenai sebuah negara yaitu Indonesia.

\section{Metode}

Tipe penelitian ini adalah penelitian eksperimen murni (true experimental design). Desain penelitian ini menggunakan desain eksperimen ulang atau pretest-postest cotrol group design. Variabel terikat (Y) pada penelitian ini adalah kecenderungan munculnya paham radikalisme sedangkan variabel bebas (X) adalah psikoedukasi wawasan kebangsaan. Subjek penelitian dipilih dari populasi yang ada di Universitas 17 Agustus 1945 dengan menggunakan teknik non probability sampling. Alat pengumpul data berupa soal pengetahuan berbentuk pertanyaan tertutup multiple choice. Kuesioner disusun menggunakan prinsip skala sikap dari linkert. Sebelum skala ukur dipakai untuk mengambil data, terlebih dahulu skala tersebut diuji validitas serta reliabilitasnya. Selanjutnya data yang telah diperoleh diuji secara statistik menggunakan uji korelasi product moment dengan program SPSS. 


\section{Hasil}

Hasil uji Paired Sample T Test diperoleh signifikasi sebesar $0.104>0.05$. Artinya tidak ada perbedaan yang signifikan antara rata-rata skala pre-test kelompok kontrol dengan skala post-test kelompok kontrol dengan kata lain kelompok kontrol yang tidak diberi psikoedukasi Wawasan Kebangsaan tidak mengalami perubahan sikap radikalisme. Lebih lanjut, hasil uji Paired Sample T Test diperoleh signifikansi sebesar $0.281>0.05$. Artinya tidak ada perbedaan yang signifikan pada rata-rata antara soal pre-test kelompok kontrol dengan soal post-test kelompok kontrol. Hal ini membuktikan bahwa kelompok kontrol tidak menunjukkan peningkatan pengetahuan mengenai radikalisme.

Grafik 1 Tabel Hasil Analisis Statistik antara Kelompok Kontrol \& Peserta Psikoedukasi

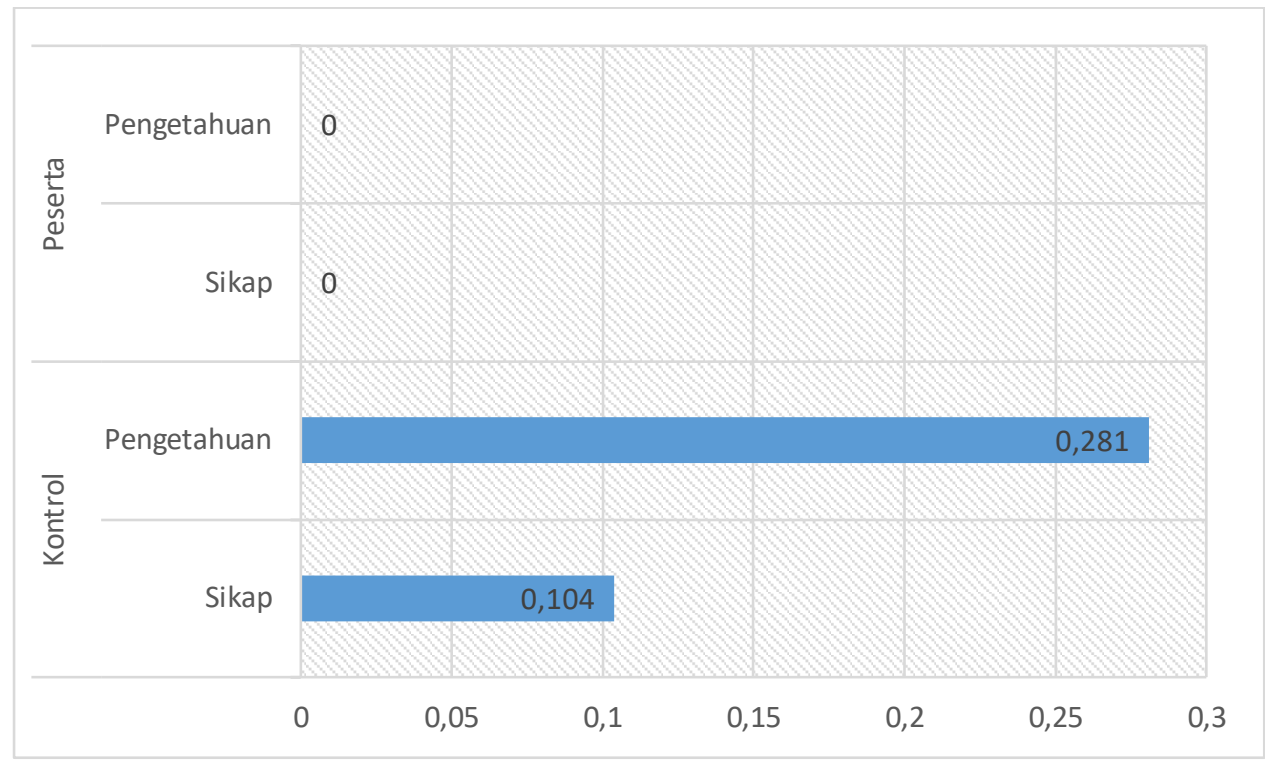

Ada pun mengenai hasil uji Paired Sample T Test skala pre-test dan post-test pada kelompok yang diberi perlakuan berupa Psikoedukasi Wawasan Kebangsaan didapatkan signifikansi sebesar $0.000<0.05$. Artinya tedapat perbedaan rata-rata antara skala pre-test dengan skala post-test. Hal ini membuktikan bahwa ada pengaruh penggunaan strategi Diskusi Wawasan Kebangsaan pada sikap mahasiswa terhadap radikalisme. Sementara itu hasil uji Paired Sample T Test soal pre-test dan post-test pada kelompok yang diberi perlakuan berupa Psikoedukasi Wawasan Kebangsaan diperoleh signifikansi sebesar $0.000<0.05$. Artinya ada perbedaan rata-rata antara jawaban dari soal pre-test dengan soal post-test. Hal ini membuktikan bahwa ada pengaruh penggunaan strategi Diskusi Wawasan Kebangsaan terhadap pengetahuan mahasiswa mengenai radikalisme. 


\section{Pembahasan}

Hasil penelitian menunjukkan bahwa psikoedukasi Wawasan Kebangsaan dapat menurunkan sikap radikalisme pada mahasiswa. pengaruh penggunaan strategi Diskusi Wawasan Kebangsaan terhadap sikap mahasiswa mengenai radikalisme. Peningkatan pembelajaran pada penelitian ini tidak hanya terjadi di aspek sikap tetapi diikuti pula dengan peningkatan pada aspek pengetahuan, terdapat perbedaan yang signifikan pada pemahaman peserta mengenai wawasan kebangsaan antara sebelum dilaksanakannya psikoedukasi berupa pelatihan dengan setelah pelatihan. Hasil yang didapat pada aspek sikap tidak terlepas dari pengetahuan yang telah dimiliki peserta pelatihan. Sikap bergantung pada pengetahuan dalam arti bahwa orang tesebut harus tahu "apa" yang harus dilakukan dan "kapan" untuk melakukannya.

Pada pelatihan ini, para peserta tidak hanya diberikan materi mengenai bagaimana sebenarnya menunjukkan sikap nasionalisme yang merupakan lawan dari sikap radikal, namun juga pengetahuan - pengetahuan yang mendasarinya, seperti pengetahuan mengenai cinta tanah air dari sudut pandang psikologi, potensi yang dimiliki oleh Indonesia baik pesona maupun tantangan yang dihadapi, multikultural, sejarah Indonesia serta gotong royong sebagai penciri Indonesia.

Hasil penelitian ini juga menunjukkan bahwa pelatihan merupakan metode yang sesuai bagi orang dewasa untuk belajar. Hal tersebut mendukung penjelasan Sukadji (2000) bahwa pendidikan orang dewasa dapat membantu orang dewasa belajar kembali, yang dapat dilakukan melalui pelatihan. Lindeman (dalam Leonard, 2002) juga menyatakan hal yang serupa yang menyatakan bahwa inti dari pendidikan orang dewasa adalah menghadirkan situasi dan pengalaman. Pelatihan wawasan kebangsaan dilakukan dengan memperhatikan makna pembelajaran orang dewasa melalui hadirnya pengalaman belajar.

Pengalaman belajar begitu penting bagi orang dewasa sehingga Kolb (1984) mengembangkan sebuah model belajar yang disebut experiential learning. Dalam skema Kolb, pelajar memiliki pengalaman nyata dimana mereka merefleksikannya. Melalui refleksi tersebut mereka dapat memfomulasikan konsep abstrak dan membuat kesimpulan yang sesuai. Maahsiswa kemudian menggabungkan pemahaman mereka dengan menguji implikasi pengetahuan yang mereka miliki dalam situasi baru. Hal ini memberi pengalaman nyata dan siklus belajar terus berlanjut (Taylor \& Hamdy, 2013).

Pengalaman belajar bagi orang dewasa melalui psikoedukasi Wawasan Kebangsaan dapat menjadi alternatif solusi atas kekhawatiran mengenai potensi berkembangnya sikap dan perilaku radikalisme yang makin marak akhir-akhir ini berupa peristiwa teror bom di berbagai kota di Indonesia. Psikoedukasi adalah salah satu bentuk pendekatan yang dapat membantu mahasiswa agar memiliki pola pikir dan sikap yang tepat mengenai tanah air mereka serta 
berbagai hal yang ada dan terjadi di dalamnya. Pola pikir yang tepat erat kaitannya dengan persepsi dalam diri seseorang, persepsi yang positif akan mendorong seseorang untuk memiliki pola pikir dan sikap yang positif pula. Persepsi yang positif tidak dapat dibangun dalam waktu sekejap, individu yang bersangkutan butuh dilatih untuk melihat suatu fenomena secara utuh tidak bagian perbagian. Psikoedukasi Wawasan Kebangsaan membantu para mahasiswa untuk melihat Indonesia secara utuh, tidak hanya hal yang baik tetapi juga tantangan-tantangan yang sedang dihadapi oleh Indonesia untuk kemudian bersama-sama mencari alternatif solusi yang ada.

Persepsi yang positif terhadap negara adalah hal penting yang harus dimiliki oleh pemuda pemudi saat ini, hal ini dikarenakan persepsi juga dapat berpengaruh pada terbentuknya sikap fundamentalis seperti yang diungkapkan oleh Ellis (2017) pada penelitiannya mengenai sikap fundamentalis relijius remaja. Menurut Ellis (2017) sikap fundamentalis yang terjadi lebih disebabkan oleh persepsi siswa terhadap pendudukan negara-negara barat di negara Islam untuk menggulingkan pemerintahan yang sah di Afrika Utara maupun di Timur Tengah. Fundamentalis yang positif inilah yang seharusnya mulai di bangun pada mahasiswa untuk mencegah munculnya sikap radikalisme yaitu dengan menambah wawasan kebangsaan untuk mengurangi perilaku radikalisme.

\section{Simpulan}

Psikoedukasi, pada penelitian ini merupakan metode yang dapat digunakan untuk menurunkan kecenderungan sikap radikalisme. Hal ini tidak terlepas dari meningkatnya pengetahuan peserta mengenai wawasan kebangsaan yang telah dikemas sesuai dengan karakteristik generasi muda. Pengalaman belajar bagi orang dewasa (generasi muda) melalui psikoedukasi Wawasan Kebangsaan dapat menjadi alternatif solusi atas kekhawatiran mengenai potensi berkembangnya sikap dan perilaku radikalisme.

Saran

Peneliti selanjutnya dapat mengaitkan tema-tema mengenai radikalisme pada generasi muda dengan perilaku toleransi antar kelompok, dan untuk dapat menghayati makna toleransi itu sendiri, setiap peserta tidak hanya diberi wawasan secara kognitif tapi juga terjun langsung ke berbagai macam kelompok dengan latar belakang yang berbeda untuk mempraktikkan toleransi itu sendiri.

\section{Daftar Pustaka}

Aly, Abdul, (2011). Pendidikan Islam Multikultural di Pesantren, Yogyakarta: Pustaka Pelajar.

Ancok, D. (2008). Ketidakadilan Sebagai Sumber Radikalisme dalam Agama: Suatu Analisis Berbasis Teori Keadilan dalam Pendekatan Psikologi. Jurnal Psikologi Indonesia 2008, No. 1, 1-8, ISSN. 0853-3098 
Cross, R. (2013). Radicalism. dalam Snow, D., della Porta, D., Klandermans, B., dan McAdam, D. (eds.). The Wiley-Blackwell Encyclopedia of Social and Political Movements. doi: 10.1002/9781405198431.wbespm175

Departemen Pendidikan Nasional. (2002). Kamus Besar Bahasa Indonesia ed. III. Jakarta: Balai Pustaka

Diktis.kemenag.go.id/NEW/index.php?berita=detil\&jenis=news\&jd=162.\#.XeyoM25uLtQ. Diakses pada tanggal 8 Desember 2019

Endang Turmudi, Riza Sihbudi. (2005). Islam dan Radikalisme di Indonesia. Jakarta: Lembaga Ilmu Pengetahuan Indonesia

Hasyim, M., dkk (2015). Diskursus Deradikalisasi Agama: Pola Resistensi Pesantren terhadap Gerakan Radikal. Jurnal Penelitian Sosial Keagamaan. UIN Wali Songo

Kolb, D. (1984). Experiential Learning: Experience as the Source of Learning and Development.

Latipun. 2004. Psikologi Eksperimen. Malang: UMM Press

McCauley, C. dan Moskalenko, S. (2008). Mechanisms of Political Radicalization: Pathways Toward Terrorism. Terrorism and Political Violence, 20:3, 415-433. doi: $10.1080 / 09546550802073367$

Moskalenko, S. dan McCauley, C. (2009). Measuring Political Mobilization: The Distinction Between Activism and Radicalism. Terrorism and Political Violence. 21:2, 239-260. doi:10.1080/09546550902765508

Nelson-Jones, R. (1982). The theory and practice of counselling psychology. London: Holt, Rinehart and Winston

Rahimullah, Riyad Hosain, Setephen Larmar, and Mohamad Abdalla. (2013). „Radicalization and Terrorism: Research within the Australian Context. "International Journal of Criminologyand Sociology. Vol. 2. Hlm 180-185.

Saifuddin, (2011). Radikalisme Islam di Kalangan Mahasiswa. Jurnal Studi Keislaman Vol. XI No. 1 (Juni, 2011), 28.

Salehuddin, A. (2012). Understanding Religious Violence In Indonesia: Theological, Structural and Cultural Analyses. Journal of Indonesian Islam. UIN Sunan Ampel Surabaya

Seniati dkk. (2005). Psikologi Eksperimen. Jakarta: PT. Indeks

Taylor, D. C. M., \& Hamdy, H. (2013). Adult learning theories: Implications for learning and teaching in medical education: AMEE Guide No. 83. Medical Teacher, 35(11), e1561-e1572. https://doi.org/10.3109/0142159X.2013. 82815 
Philanthrophy: Journal of Psychology

Volume 3 Nomor 2, Desember 2019: 89-97
ISSN 2580-6076; E-ISSN 2580-8532

DOI : 10.26623/philanthropy.v3i2.1651 